\title{
CONHECIMENTO COMO FRUTO PROIBIDO NA BIBLIOTECA LABIRÍNTICA DE O NOME DA ROSA
}

\author{
KNOWLEDGE AS FORBIDDEN FRUIT IN THE THE NAME OF THE ROSE'S \\ LABYRINTHINE LIBRARY
}

Cynthia Beatrice Costa ${ }^{1}$

Conhecimento e poder coincidem. ${ }^{2}$

Francis Bacon

\begin{abstract}
Resumo: Ao traçar um paralelo entre o fruto proibido do Gênesis e o livro proibido em torno do qual gira a trama de $O$ nome da rosa (1980), de Umberto Eco, o presente artigo propõe uma interpretação ciente de que há diversas outras possíveis - para a biblioteca labiríntica retratada no romance. Em meio ao enfrentamento entre monges que desejam acesso ao conhecimento e monges que interditam esse acesso, julgando-o perigoso, pode-se perceber na abadia criada por Eco alusões à queda de Adão e Eva, que são expulsos do Éden por experimentarem o fruto da árvore do conhecimento do bem e do mal. A partir do estudo de símbolos (BIEDERMAN, 1992; CIRLOT, 2001; FERBER, 2007; TRESSINDER, 2012), de considerações a respeito do mito fundador bíblico (COTTER, 2003; TOWNER, 2001) e de explicações sobre o labirinto dadas pelo próprio autor (1985; 2017), procura-se investigar relações entre proibição, autoridade e conhecimento no contexto do livro.
\end{abstract}

Palavras-chave: $O$ nome da rosa; simbologia do labirinto; Gênesis; conhecimento como fruto proibido

Summary: By drawing a parallel between the forbidden fruit of Genesis and the forbidden book of Umberto Eco's The Name of the Rose (1980), this paper proposes an interpretation - aware that there are several other possible ones - to the labyrinthine library portrayed in the novel. Amid the confrontation between monks who yearn for access to knowledge and monks who forbid such access, judging it dangerous, one can see in the abbey created by Eco allusions to the fall of Adam and Eve, who are expelled from Eden for eating the fruit of the tree of the knowledge of good and evil. Based on the study of symbols (BIEDERMAN, 1992; CIRLOT, 2001; FERBER, 2007; TRESSINDER, 2012), considerations about the biblical founding myth (COTTER, 2003; TOWNER, 2001) and explanations about the labyrinth provided by the author himself $(1985 ; 2017)$, it seeks to investigate relationships between prohibition, authority and knowledge in the book's context.

Keywords: The Name of the Rose; symbolism of labyrinth; Genesis; knowledge as forbidden fruit.

\footnotetext{
${ }^{1}$ Mestre em Literatura e Crítica Literária e doutora em Estudos da Tradução. Professora do curso de Tradução do Instituto de Letras e Linguística (ILEEL) da UFU.

${ }^{2}$ Tradução de "Scientia et potentia humana in idem coincidunt", do Livro I de aforismos do Novum Organum (1620), de Francis Bacon (1878, p. 188). O filósofo finlandês Georg Henrik Wright (1993, p. 127) lembra que o lema "conhecimento é poder" atribuído a Bacon não passa de uma adaptação de algumas máximas suas, como essa.
} 
No romance $O$ nome da rosa $(1980)^{3}$, de Umberto Eco, o monge Adso de Melk narra acontecimentos de sua juventude longínqua, de quando tivera a oportunidade de acompanhar o frade franciscano Guilherme de Baskerville, de quem era discípulo, na investigação de crimes ocorridos em uma abadia italiana. Passada no século XIV, a aventura detetivesca vivida pelos dois, tal qual rememorada por Melk, coloca-se, por um lado, como um comentário teólogofilosófico - com longos debates entre franciscanos e beneditinos - e, por outro, como uma crônica medieval (GUIMARÃES, 1988, p. 209) ou, até mesmo, como uma distopia bibliotecal (GARRETT, 1991, p. 377)

Já indica o sobrenome "Baskerville" (de O Cão dos Baskervilles, de Sir Arthur Conan Doyle) que Guilherme de Baskerville e Adso de Melk retomam os papéis de Sherlock Holmes e Dr. Watson, com Adso fazendo as vezes de ajudante e narrador da investigação - é por meio dele que conhecemos a perspicácia de seu mestre, cujo nome homenageia também o frade inglês Guilherme de Ockham ${ }^{4}$ (c. 1285-1349). Este integra a narrativa como um amigo pessoal de Guilherme de Baskerville, a quem escreve cartas (ECO, 2017, p. 239; p. 328-329). As ideias defendidas pelo protagonista remetem às de Roger Bacon e de São Tomás de Aquino (HAFT, WHITE e WHITE, 1999, p. 17), e, pode-se arriscar dizer ainda, Guilherme é construído como um alter ego do próprio Eco, sendo ambos estudiosos de signos. Ao longo do romance, Guilherme ensina Adso "a reconhecer os traços com que nos fala o mundo como um grande livro" (ECO, 2017, p. 61).

Desde o seu lançamento, $O$ nome da rosa tem sido abordado como um caso de adoção de recursos narrativos pós-modernos em uma revisitação à Idade Média (GUIMARÃES, 1988, p. 209). Baseando-se em estudos históricos minuciosos, Eco escolheu um período específico a chegada de Guilherme e Adso à abadia se dá em novembro de 1327 -, cercado de acontecimentos relevantes para a Ordem Franciscana, como a ida de Miguel de Cesana a Avignon para debater com o Papa João XXII a questão da pobreza de Cristo (BAXTER, 1989,

\footnotetext{
${ }^{3} \mathrm{O}$ título original é Il nomo della rosa. A tradução usada para a análise no presente artigo é de Aurora Fornoni Bernardini e Homero Freitas de Andrade, publicada pela editora Record.

${ }^{4}$ Também grafado Occam (TERZIEVA-ARTEMIS, 2009, p. 174).
} 
p. 172). Entrelaça, portanto, fatos e nomes históricos com eventos e personagens fictícios, tornando com frequência difícil a distinção entre uns e outros.

No prólogo "Um manuscrito, naturalmente", Eco afirma ter chegado às mãos dele, em 1968, um manuscrito do século XIV de um certo Dom Adso de Melk, originalmente escrito em latim, mas que já teria passado por diversas edições e traduções (ECO, 2017, p. 41). O manuscrito fora perdido em uma viagem, porém, e sua veracidade apenas confirmada por ele dois anos depois, em Buenos Aires, ao encontrar na versão castelhana do livro Do uso dos espelhos no jogo de xadrez, de Milo Temesvar, "copiosas citações do manuscrito de Adso" (ECO, 2017, p. 43).

Tudo isso não passa de ficção criada pelo autor, mas serve de antecipação ao romance que se seguirá ao prólogo: ao citar Buenos Aires, Eco alude a Jorge Luis Borges ${ }^{5}$, que será homenageado ao longo de todo o livro na figura do venerável Jorge de Burgos, protetor obsessivo da biblioteca labiríntica e vilão da trama. O título do livro fictício pode referir-se, por sua vez, aos jogos de lógica (como o xadrez) tão cultivados por Guilherme em sua investigação dos assassinatos, que só serão solucionados, à maneira carrolliana, ao se atravessar um espelho.

Símbolo da vaidade intelectual (GARRETT, 1991, p. 377), a biblioteca da abadia em que ocorrem os crimes investigados por Guilherme e Adso é disposta como um labirinto. Foi particularmente pela descrição desse labirinto - idêntica no manuscrito e no livro de Temesvar - que Eco diz ter confirmado a veracidade do manuscrito de Melk. Em mais essa ilusão construída pelo autor, está o anúncio de que o labirinto constitui um elemento central do enredo, e que, como todo o restante, coloca-se aberto a interpretações. Eco, afinal, sempre se posicionou como um defensor da multiplicidade de interpretações da obra literária, "como contínua possibilidade de aberturas, reserva indefinida de significados" (ECO, 1991, p. 47). Seu protagonista, Guilherme, expressa um ponto de vista similar: "O bem de um livro está em ser lido. Um livro é feito de signos que falam de outros signos, os quais por sua vez falam das coisas. Sem um olho que o leia, um livro traz signos que não produzem conceitos, e portanto é mudo" (ECO, 2017, p. 423).

\footnotetext{
${ }^{5}$ Haft, White e White julgam a relação de Eco e Borges como de amor e ódio literário (1999, p. 27), daí a escolha do autor italiano de retratar Borges como o vilão, ao mesmo tempo em que o homenageia. A biblioteca labiríntica de $O$ nome da rosa também claramente homenageia o conto "A biblioteca de Babel", assim como os temas de manuscritos, livros, labirintos e espelhos, muito comuns na obra do escritor argentino (HAFT, WHITE e WHITE, 1999, p. 28). Eco citou o conto de Borges em sua palestra “De bibliotheca”, proferida em Milão em 1981.
} 
No "Pós-escrito" do romance, Eco esclarece que o seu labirinto é, como outros labirintos, "um modelo abstrato de conjecturabilidade" (ECO, 2017, p. 549). E acusa o leitor ingênuo de achar "que se encontrava diante de uma história de labirintos espaciais" (ECO, 2017, p. 550). Está posto, assim, o convite para as mais variadas leituras, que não são poucas. Há, por exemplo, quem interprete o próprio romance como um labirinto literário, diante do qual não sabemos como nos colocar como leitores (TERZIEVA-ARTEMIS, 2009, p. 180). As discussões sinuosas entre os monges, que parecem não ter fim nem resolução, também remetem à frustração de Sócrates no diálogo "Eutidemo", quando compara um debate filosófico infrutífero à queda em um labirinto (FERBER, 2007, p. 106). Labirintos, afinal, são tão enigmáticos quanto o seu simbolismo (TRESSINDER, 2012, p. 127) e podem equivaler a qualquer coisa impenetrável e inextricável (FERBER, 2007, p. 106).

O presente texto examina a biblioteca labiríntica de Eco ao sugerir um paralelo entre o "livro proibido" (ECO, 2017, p. 421) de O nome da rosa e o fruto proibido do Gênesis bíblico. $\mathrm{Na}$ primeira parte, contextualiza-se o labirinto no romance; são elencadas diferentes interpretações com base em dicionários de símbolos e estudos a respeito da figura do labirinto na literatura (BIEDERMAN, 1992; CIRLOT, 2001; FERBER, 2007; TRESSINDER, 2012), levando em consideração, ao mesmo tempo, os comentários feitos pelo próprio autor (ECO, 1985; 2017) a respeito do labirinto que criou para o livro. Na segunda parte, propõe-se a análise interpretativa, apoiada na tradução do Gênesis para o português brasileiro de Alexandro Zir e em considerações de estudiosos da Bíblia (COTTER, 2003; TOWNER, 2001).

\section{Biblioteca labiríntica}

Toda a trama de $O$ nome da rosa gira em torno da biblioteca e de certo livro misterioso que nela está guardado. Disposta como um labirinto para impedir que não iniciados acessem o acervo, a biblioteca é abrigada na torre do Edifício, onde fica também o scriptorium, no qual os monges trabalham copiando, traduzindo e ilustrando livros. É do alto da torre que despenca Adelmo, o primeiro de uma série de monges que aparecem mortos. Assim, é à biblioteca, evidentemente, que se volta a atenção de Guilherme ao chegar ao mosteiro e receber do Abade a incumbência de ajudá-lo na investigação da queda de Adelmo.

Como se tem examinado ao longo dos anos, a arquitetura do Edifício é fantasiosa do ponto de vista histórico, sobretudo por sua quantidade de janelas envidraçadas - inimagináveis 
para a Europa da Alta Idade Média (GARRETT, 1991, p. 375). Sabe-se, porém, que não se trata de um equívoco por parte de Eco, mas de um de seus anacronismos propositais, à maneira pósmoderna. Ao falar de sua experiência escrevendo o romance, ele mencionou a preocupação em adicionar brechas para que o ar circulasse no labirinto (ECO, 1985, p. 9).

De início, sabemos que não se trata de uma biblioteca qualquer. Observa Guilherme: "Sei que tem mais livros que qualquer outra biblioteca cristã" (ECO, 2017, p. 73). Malaquias, o bibliotecário, deixa claro que apenas ele pode conhecer os livros e as suas respectivas localizações de memória, e que é em sua memória que os outros monges devem confiar (ECO, 2017, p. 112). Apenas três iniciados - o bibliotecário, seu ajudante e o Abade - conhecem os segredos da biblioteca, passados de geração em geração.

É o Abade que se refere à biblioteca pela primeira vez como um labirinto, ao esclarecer para Guilherme - que está inconformado com a impossibilidade de visitá-la - as regras de circulação pelo Edifício. O Abade ressalta: "Somente o bibliotecário, além de saber, tem o direito de mover-se no labirinto dos livros, somente ele sabe onde encontrá-los e onde guardálos, somente ele é responsável pela sua conservação" (ECO, 2017, p. 75).

Não são raras as passagens em que a biblioteca é ou antropomorfizada, ou hipervalorizada em sua inacessibilidade. Ela corre o risco de ser "violada" (ECO, 2017, p. 175) e não deveria ser ameaçada "por nenhuma força terrena, pois era uma coisa viva...” (ECO, 2017, p. 219). Não sem razão, um monge acusa o Abade de conduzir "a abadia como uma cidadela erigida em defesa da biblioteca" (ECO, 2017, p. 159). Sua disposição labiríntica a torna atraente e, ao mesmo tempo, dissimulada e cruel, tal qual a Esfinge de Sófocles, que devora os que não conseguem decifrar os seus enigmas (KURY, 2011, p. 8).

Labirintos podem ser relacionados a rituais religiosos e de iniciação, e a biblioteca de $O$ nome da rosa certamente parece confirmar essa simbologia. Nas catedrais medievais, labirintos eram entendidos como "estradas para Jerusalém" (BIEDERMAN, 1992, p. 200), isto é, equivalentes a peregrinações. Ao conduzir Guilherme e Adso a uma nova etapa de entendimento, alude também à jornada do herói, como no mito grego de Teseu, que mata o Minotauro no labirinto da Ilha de Creta com a ajuda do novelo de Ariadne (FERBER, 2007, p. 106) - Guilherme, por sinal, recorre mais de uma vez a Ariadne em suas tentativas de dominar a biblioteca: "Talvez não consiga lembrar direito a regra, ou talvez para andar por um labirinto

\footnotetext{
${ }^{6}$ Fiz esta e outras traduções de citações ao longo do artigo: "roads to Jerusalem".
} 
seja necessário ter uma boa Ariadne que te espera à porta segurando a ponta de um fio" (ECO, 2017, p. 248).

A relação entre Guilherme e Adso e a biblioteca labiríntica apresenta três fases ao longo do romance: primeiramente, eles ficam sabendo da proibição de entrar nela e tentam descobrir como driblar essa proibição; depois, conseguem desvendar o mistério da entrada e penetram no labirinto, mas não conseguem solucioná-lo; por fim, conseguem solucionar o labirinto com base na lógica, ao observá-lo de fora, e chegam ao desenlace final - isto é, em meio às salas interconectadas, do outro lado de um espelho, encontram Jorge agarrado ao misterioso livro que desencadeara todas as mortes. Vencer o labirinto pode ser visto como um símbolo de conclusão, de término de uma missão (HAFT, WHITE e WHITE, 1999, p. 29), e é assim que se encerra a aventura de Guilherme e Adso.

A descrição do labirinto é rica em detalhes, e o romance traz até mesmo uma ilustração do mapa do labirinto composto por Adso sob a orientação de Guilherme (ECO, 2017, p. 351). Ajuda a compreendê-lo também a explicação dada por Eco no "Pós-escrito a $O$ nome da rosa", em que ele lista três tipos de labirinto: o grego, de Teseu; o maneirista, que seria uma espécie de árvore, "uma estrutura de raízes com muitos becos sem saídas" (ECO, 2017, p. 550); e a rede que Deleuze e Guattari chamam de rizoma, composto de tal maneira que cada entrada possa se conectar com qualquer outra. Conclui, então: "O labirinto de minha biblioteca ainda é um labirinto maneirista, mas o mundo no qual Guilherme percebe estar vivendo já é estruturado em rizomas, ou seja, é estruturável, mas nunca estruturado definitivamente" (ECO, 2017, p. 550).

O rizoma proposto por Deleuze e Guattari é bastante abstrato, composto por "cadeias semióticas de toda natureza conectadas", de modo que "não se pode estabelecer um corte radical entre os regimes de signos e seus objetos" (DELEUZE e GUATARI, 2000, p. 14). Vogl (2007) vê esse rizoma como um labirinto sem começo nem fim, sem centro nem periferia, no qual a ajuda do fio de Ariadne seria, portanto, inútil. Nesse labirinto feito exclusivamente de atalhos e de encontros imprevistos, não se sabe qual passagem levará à próxima, nem como. De fato, a saga de Guilherme contra o arqui-inimigo Jorge, como fica claro na cena final entre os dois, possui mais tropeços, coincidências e imprevistos do que uma lógica linear e irrefutável. Ao contrário da hipótese construída por Guilherme, os incidentes na abadia não simulavam o 
Apocalipse de João ${ }^{7}$. As tantas discussões acerca da pobreza de Cristo também não impactam a solução final (HAFT, WHITE e WHITE, 1999, p. 183).

No capítulo "Segundo dia - noite", em que "finalmente se penetra no labirinto, tem-se estranha visões e, como acontece nos labirintos, fica-se perdido nele" (ECO, 2017, p. 202), Guilherme e Adso aventuram-se pelo labirinto pela primeira vez e confirmam a noção que se tem, em geral, de labirintos, como "uma estrutura arquitetônica, aparentemente sem objetivo, e de um padrão tão complexo que, uma vez dentro, é impossível ou muito difícil escapar"9 (CIRLOT, 2001, p. 173). Exceto que, nesse caso, o labirinto tem um objetivo claro, de manter quem quer que seja longe dos livros ali guardados. Apenas em sua segunda incursão é que a dupla alcança finis Africae, seção de poetas africanos onde deve estar um certo livro proibido objeto de desejo, supõem eles, dos monges que apareceram mortos.

Sinal de sua vaidade intelectual, a princípio Guilherme julga o labirinto mais fácil do que realmente é (ECO, 2017, p. 203). Depois, descreve a Adso a única maneira conhecida de se escapar de um labirinto, ou seja, percorrendo todas as suas partes; ele afirma ter lido sobre isso em um livro antigo (ECO, 2017, p. 209). Mais tarde, pensa que uma "máquina maravilhosa", que apontasse sempre na mesma direção, seria a chave para vencerem o labirinto (ECO, 2017, p. 246-247). No fim das contas, porém, conseguem sair mais por acaso do que por método. Descobrem que há no labirinto salas quase idênticas, algumas com janelas e outras sem, e inscrições do livro do Apocalipse de João nas paredes. Todas as salas seguem padrões geométricos, sendo a principal uma sala heptagonal ${ }^{10}$.

Em determinado ponto do labirinto, há um espelho, que de início aterroriza os dois invasores: "Um espelho, que devolve a tua imagem aumentada e distorcida" (ECO, 2017, p. 205), diz Guilherme rindo, ao consolar Adso após o susto. Obviamente, há razão para o espelho estar ali. Instrumento de autocontemplação e/ou de contemplação do universo (CIRLOT, 2001, p. 211), o espelho convida o homem inevitavelmente a encontrar o seu outro eu (HAFT, WHITE

\footnotetext{
${ }^{7}$ As experiências pessoais de Adso de Melk, com suas visões e sonhos, são por vezes relacionadas ao Apocalipse de João (HAFT, WHITE e WHITE, 1999, p. 177-184).

${ }^{8}$ Como é esclarecido após o prólogo e antes do início do romance propriamente dito, o manuscrito de Adso está dividido em sete dias e, cada um dos dias, em períodos correspondentes às horas litúrgicas: Matinas, Laudes, Prima, Terça, Sexta, Noa, Vésperas e Completas (ECO, 2017, p. 47). Além disso, todo capítulo começa com uma epígrafe que resume os fatos que serão narrados.

9 "apparently aimless, and of a pattern so complex that, once inside, it is impossible or very difficult to escape".

${ }^{10} \mathrm{O}$ número sete é recorrente em $O$ nome da rosa, espelhando a sua relevância no Apocalipse de João, em que esse número se repete diversas vezes (HAFT, WHITE e WHITE, 1999, p. 180). Toda a ação se passa em sete dias, e Guilherme chega a comentar que sete é o "número místico mais que os outros” (ECO, 2017, p. 472).
} 
e WHITE, 1999, p. 181). Antes de atravessá-lo, portanto, Guilherme e Adso têm de enfrentar a si mesmos.

No labirinto, Adso é envenenado por uma erva alucinógena que o faz delirar. “Alguém põe ervas mágicas durante a noite para convencer os visitantes inoportunos de que a biblioteca é defendida por presenças diabólicas" (ECO, 2017, p. 208), diz Guilherme, remetendo a uma relação conhecida entre labirintos e entidades maléficas - acredita-se que alguns labirintos na Ásia e na Europa tenham sido construídos para atrair e aprisionar demônios (CIRLOT, 2001, p. 173). Está claro a Guilherme, porém, que as dificuldades encontradas ali são obra bastante humana: "Ervas, espelhos... Este lugar de sabedoria proibida é protegido por muitos e sapientíssimos achados. A ciência usada para ocultar, em vez de iluminar. Não me agrada. ${ }^{11}$ Uma mente perversa preside a santa defesa da biblioteca" (ECO, 2017, p. 208). Guilherme define, assim, um inimigo a ser enfrentado, o dono da "mente perversa" que protege a "sabedoria proibida".

A imagem do labirinto como protetor de segredos também não é incomum. Ao abordar os thôma (maravilhas, curiosidades; HARTOG, 1999, p. 245) dos relatos de viagem de Heródoto, Hartog interpreta o labirinto do Egito visitado por ele como um thôma que se coloca como cifra. Heródoto afirma que havia salas inferiores proibidas, das quais apenas ouviram dizer, ao passo que viram com os próprios olhos as salas superiores. A imagem do labirinto vem, portanto, acompanhada de um maravilhamento por sua complicação e por seus segredos. "Heródoto procede à distinção entre o que viu (as salas superiores) e o que não se deixou que ele visse (as salas inferiores), falando do que não viu por 'ouvir dizer'” (HARTOG, 1999, p. 281).

Assim também são as experiências iniciais de Guilherme e Adso na biblioteca de $O$ nome da rosa, pois sabem que há algo de importante ali, embora ainda não consigam ver. Ao conseguirem escapar, enfim, e sentirem o frescor da noite, Adso exclama, aliviado: "Como é belo o mundo e como são horríveis os labirintos!", ao que Guilherme responde: "Como seria belo o mundo se houvesse uma regra para andar nos labirintos!” (ECO, 2017, p. 211). Não é a

\footnotetext{
${ }^{11}$ Em seu discurso "De bibliotheca", Eco denuncia a mesma coisa: "É preciso escolher se se quer proteger os livros ou proporcionar a leitura deles. Não digo que é preciso escolher proporcionar a leitura sem protegê-los, mas não se deve também escolher protegê-los sem proporcionar a leitura" (2004, p. 10).
} 
complicação que assusta o frade franciscano, pelo contrário, ela lhe causa maravilhamento; é o fato de não a ter solucionado ainda que o aflige.

No desenlace da trama, sabemos que Jorge de Burgos, responsável pelos assassinatos, é também um iniciado na biblioteca, pois fora ajudante de bibliotecário décadas atrás. É ele que não quer tornar conhecido o tratado sobre a comédia de Aristóteles, o "livro proibido" de que todos os envolvidos nos crimes da abadia estão atrás. Jorge tem medo de que as pessoas, graças ao riso, percam o medo e, consequentemente, a fé. "O riso é incentivo à dúvida", declara (ECO, 2017, p. 167). Ele acredita que "a lei é imposta pelo medo, cujo nome verdadeiro é temor a Deus" e que o "o riso libera o aldeão do medo do diabo", sendo usado, assim, como uma "arma sutil" (ECO, 2017, p. 502-503). Ironicamente, ele morre devorando o livro que protegia - e rindo: "Riu, logo ele, Jorge" (p. 508).

Apesar de cego, Jorge circula com maestria pelo labirinto. É ele que complica a experiência daquele que se arrisca por ali, envenenando as páginas dos livros de forma que a vítima curiosa tenha alucinações, e de maneira que a biblioteca ganhe fama de tornar loucos os que se embrenham por ela, como descreve o vidreiro Nicola: "Digamos, de um monge que à noite quis se aventurar na biblioteca, por magia, e viu serpentes, homens sem cabeça, e homens com duas cabeças. Por pouco não saía louco do labirinto...” (ECO, 2017, p. 126).

Um labirinto enlouquecedor é o obstáculo perfeito para proteger o conhecimento dos não iniciados. Contudo, é esse mesmo labirinto que acaba por destruir o conhecimento contido nele, quando a biblioteca, enfim, pega fogo. "A biblioteca fora condenada por sua própria impenetrabilidade, pelo mistério que a protegia, pela exiguidade de seus acessos" (ECO, 2017, p. 516), lamenta Adso diante da confirmação do que predissera Guilherme: "Esta biblioteca talvez tenha nascido para salvar os livros que contém, mas agora vive para sepultá-los" (ECO, 2017, p. 423).

Na próxima parte, será abordado um paralelo entre a proibição decretada por Deus no Gênesis e a interdição da biblioteca em $O$ nome da rosa.

\section{Proibição e queda}

Em $O$ nome da rosa, a biblioteca em forma de labirinto torna inacessível aos não iniciados o conhecimento que detém. A ironia de um lugar que guarda conhecimentos ser 
protegido a ponto de ninguém conseguir acessá-los é evidenciada no clímax final, quando a biblioteca termina incendiada e os conhecimentos ali guardados, para sempre perdidos.

Ao longo do livro, o Abade insiste na legitimidade da precaução contra possíveis leitores curiosos. Ressalta que somente o bibliotecário sabe "que tipo de segredos, de verdades ou de mentiras" há nos livros (ECO, 2017, p. 75). Sua proibição de entrada na biblioteca é categórica: "Ninguém deve. Ninguém pode. Ninguém, querendo, chegaria ali. A biblioteca defende-se por si, insondável como a verdade que abriga, enganadora como a mentira que guarda. Labirinto espiritual, é também labirinto terreno. Poderíeis entrar e poderíeis não sair” (ECO, 2017, p. 76).

Carregadas de simbolismo, as palavras do Abade sugerem que o labirinto - instância não apenas arquitetônica, como também espiritual - pode ser um caminho sem volta. Ali, verdades e mentiras poderão ser confundidas, levando mesmo os mais inocentes à perdição fatal: não mais poder distinguir entre a verdade, que é insondável, e a mentira, que é enganadora.

Descrita desse modo, como detentora tanto do bem quanto do mal, a biblioteca labiríntica assemelha-se à árvore do Jardim do Éden, no primeiro livro da Bíblia, Gênesis. Ao colocar o homem recém-criado no jardim, Deus lhe dá a ordem: “Tu podes comer de todas as árvores do jardim. Mas não coma da árvore do conhecimento do bem e do mal, porque tu morrerás no dia que comeres dela" (2001, p. 15). É criada, então, a mulher, que dá ouvidos à serpente, "o mais astuto de todos os animais que Deus criara sobre os campos": "Vós não morrereis, mas Deus sabe que vossos olhos se abrirão no dia em que comerdes desse fruto, e vós sereis como deuses, conhecendo o bem e o mal" (2001, p. 16). Há quem interprete a serpente do Gênesis também como um símbolo labiríntico, devido à sua forma sinuosa (SWAIM, 1972, p. 130).

A mulher se sente atraída pela árvore ao perceber que esta poderá lhe trazer entendimento:

\begin{abstract}
A mulher viu que a árvore era boa para comer e agradável à vista, e que era importante para despertar o entendimento. Ela tomou seu fruto e comeu. Ela deu o fruto também a seu marido, que estava junto dela, e ele o comeu.

Os olhos de um e de outro se abriram, eles perceberam que estavam nus e cobriram-se com folhas de figueira. Ouviram, então, a voz de Deus, que passava pelo jardim à tarde, e o homem e sua mulher esconderam-se longe da face de Deus, em meio às árvores do jardim. (Gênesis, 2001, p. 16-17)
\end{abstract}

Ironicamente, a serpente estava correta. Após comerem o fruto, ao contrário do que lhes dissera Deus, o homem e a mulher não morrem: em vez disso, ganham entendimento. A sua 
imediata percepção da nudez simbolizaria a perda da inocência, pois antes "estavam ambos nus, e não sentiam nenhuma vergonha" (Gênesis, 2001, p. 16). A serpente, em sua dissimulação, já sabia o que era bem e mal, portanto tinha um conhecimento antes ignorado pelos humanos; agora, como a serpente e como Deus, o homem e a mulher também sabem. Diz Deus: "Eis que o homem tornou-se como um de nós, pelo conhecimento do bem e do mal. Evitemos, agora, que ele avance sua mão e tome da árvore da vida, que ele coma dela e que ele viva eternamente" (Gênesis, 2001, p. 18).

Towner (2001, p. 44) chama a atenção para o fato de não ser a árvore da vida, que lhes garantiria a imortalidade, que tenta o homem e a mulher, mas sim a árvore do conhecimento do bem e do mal - indicando uma preferência, ou curiosidade, do ser humano pelo conhecimento acima até mesmo da imortalidade. A própria proibição de Deus restringe-se à árvore do conhecimento do bem e do mal, e só depois, no momento da expulsão do homem e da mulher do Éden, é que Ele menciona a árvore da vida.

Mas por que Deus os proibiria de ter conhecimento? Interpretações do Gênesis sugerem a proibição de Deus como uma forma de manter a humanidade dependente de seus comandos, ou ignorante com relação à sexualidade, ao prazer e à dor. Há, ainda, a possibilidade de afastála do conhecimento universal, já que bem e mal poderiam significar "tudo". A proibição pode ser vista, enfim, como arbitrária, um exercício de autoridade por parte de Deus (COTTER, 2003, p. 30).

Como se pode notar, há ecos de toda a cena mítica do Gênesis ao longo de $O$ nome da rosa. Segundo a ordem do Abade, Guilherme e Adso podem circular por todos os lugares, exceto pela biblioteca. Esta, como labirinto maneirista sugerido por Eco (2017, p. 550) é como uma árvore que se abre em ramificações. Quando, após três incursões diferentes (quatro para Adso, como será comentado adiante), os dois conseguem finalmente desvendar o código para passar pelo grande espelho, encontram Jorge de Burgos com o livro proibido de Aristóteles nos braços - trata-se do fruto tão desejado por Guilherme, pois este espera obter entendimento, mas que é devorado por Jorge para que ninguém mais o conheça. Não à toa, o livro é de Aristóteles, o "mestre daqueles que sabem" (BAXTER, 1989, p. 176). Jorge come as páginas (literalmente) envenenadas do livro e, na luta corporal com Guilherme, acaba derrubando um lume, assim ateando fogo na torre da biblioteca e, por fim, na abadia como um todo; o inferno toma conta do lugar. A conquista do fruto proibido leva à queda e à ruína - da gênese, salta-se diretamente ao apocalipse. Guilherme chora ao assistir ao incêndio da biblioteca. 
Dias antes, Jorge já havia dito a Guilherme que "a biblioteca é testemunha da verdade e do erro" (ECO, 2017, p. 164), uma indicação de toda a ambiguidade com que é tratado o conhecimento em $O$ nome da rosa - e também no Gênesis, em que o "entendimento" da mulher e do homem lhes abre os olhos ("os olhos de um e de outro se abriram"), mas também lhes instaura a culpa e a punição de Deus. Jorge, descrito por Adso como "omnipresente em todos os lugares da abadia" (ECO, 2017, p. 164) e como "a própria memória da biblioteca e a alma do scriptorium" (ECO, 2017, p. 165), faz as vezes do Deus punidor, controlando o que deve ou não ser sabido. O Abade e o bibliotecário, conclui-se, não passavam de marionetes suas.

Invasores bem-sucedidos, que solucionassem a biblioteca-labirinto, desafiariam a soberania de Jorge ao se tornarem semelhantes seus em matéria de conhecimento, tal como experimentar da árvore proibida permitiu que a primeira mulher e o primeiro homem assemelhassem-se a Deus. E, assim como Deus no Gênesis, Jorge não tolera essa semelhança. Com a sua queda suicida da torre da biblioteca em direção ao precipício, Adelmo simboliza a primeira expulsão: o conhecimento recém-adquirido o atira para fora de seu Éden.

"A biblioteca é um grande labirinto, signo do labirinto do mundo. Entras e não sabes se sairás" (ECO, 2017, p. 191-192). E, adiante: "E um de nós violou a proibição, rompeu os selos do labirinto... [...] Eu ouvi, todos sussurram que o pecado entrou na abadia" (ECO, 2017, p. 193). Essas duas falas do ancião Alinardo são instigantes do ponto de vista da presente discussão. Se o labirinto é signo do mundo (portanto, representação do mundo), por que deveriam temê-lo? Porque, uma vez obtido o conhecimento de mundo, já não se pode deixar de "conhecê-lo". Romper os selos do labirinto é, como experimentar o fruto proibido, um caminho sem volta - o pecado que "entrou na abadia" é o pecado do saber, e dele já não há mais como se livrar. Com o rompimento dos selos do labirinto, a abadia padece e é invadida depois por répteis (ECO, 2017, p. 525), animais feitos inimigos do ser humano no Gênesis. Diz Deus à serpente: "Colocarei inimizade entre ti e a mulher, entre a tua descendência e a dela. Esta te esmagará a cabeça, e tu lhe ferirás o calcanhar" (2001, p. 17).

Adão e Eva desvendam o "labirinto do mundo" ao comerem do fruto. O parto passa a ser doloroso ("Tu darás à luz com dor"; Gênesis, 2001, p. 17); o trabalho nos campos, necessário para a sobrevivência ("Durante todos os dias de tua vida, será à força do trabalho que conseguirás comida"; Gênesis, 2001, p. 17); e a morte, certa ("porque tu és pó e tu retornarás ao pó"; Gênesis, 2001, p. 18) - ou seja, o mundo, antes Éden, torna-se o mundo implacável como o conhecemos. 
Se a possibilidade de entendimento é capaz de seduzir Eva, até então inocente, não é necessária a lábia de uma serpente para seduzir os monges de $O$ nome da rosa, que de inocentes nada têm. Adso reflete sobre isso:

\begin{abstract}
Não me surpreendia que o mistério dos crimes rodasse em torno da biblioteca. Para esses homens debotados à escritura, a biblioteca era ao mesmo tempo a Jerusalém celeste e um mundo subterrâneo no limite entre a terra desconhecida e os infernos. Eles eram dominados pela biblioteca, por suas promessas e por suas proibições. Viviam com ela, por ela e talvez contra ela, aguardando culposamente o dia de violar todos os seus segredos. Por que não deveriam arriscar a vida para satisfazer a curiosidade de sua mente, ou matar para impedir que alguém se apropriasse de um seu bem guardado segredo? Tentações, claro, vaidade da mente. (ECO, 2017, p. 217)
\end{abstract}

A violação da biblioteca, tentação que é, não vem, porém, desacompanhada de culpa, pois os monges já intuem que o saber encerrado ali terá efeito sobre a sua fé. Sentem, assim, uma culpa por antecipação. Guilherme acredita, inclusive, que o labirinto já conta com isso a seu favor, pois aquele que tenta percorrê-lo se encontra "agitado por um senso de culpa" (ECO, 2017, p. 250) e, portanto, tem mais dificuldade de raciocinar e escapar.

O saber é visto por alguns dos monges como uma exclusividade de Deus. Não caberia aos homens buscá-lo. Quando Ubertino de Casale questiona Adso a respeito de possíveis "ânsias da carne", o noviço responde que está sofrendo mais de "ânsias da mente", o que é considerado ainda pior pelo velho franciscano: "E isso é mau. O Senhor é que conhece as coisas, a nos cabe somente adorar a Sua sabedoria” (ECO, 2017, p. 254). A conversa com Ubertino, porém, parece ter efeito contrário sobre Adso, afinal, proibição e tentação parecem caminhar juntas, como bem mostra o mito fundador do Gênesis.

Adso decide explorar sozinho a biblioteca, ainda que tema se defrontar com outro espelho, "porque tamanha é a magia dos espelhos, que mesmo que saibas que são espelhos eles não param de inquietar-te" (ECO, 2017, p. 271). Lá dentro, vê labirintos entrelaçados estampados nos pergaminhos, "que pareciam todos aludir ao novelo de salas e corredores" em que se achava (ECO, 2017, p. 272). É o momento da sua descoberta de que os livros, assim como os espelhos, podem refletir a realidade: "Ver representado naqueles pergaminhos o meu vagar me encheu de inquietação e me convenceu de que cada um daqueles livros narrava, por misteriosas zombarias, a minha história daquele momento" (ECO, 2017, p. 272).

Aqui, o labirinto representa um processo de autodescoberta (TRESSINDER, 2012, p. 127). O que ocorre com Adso é, de fato, o que teme Jorge: por meio de "misteriosas zombarias", 
ele acessa o autoconhecimento. E este o conduz ao pecado. A experiência arrebatadora na biblioteca o faz pensar em mulheres belas - era também carnal, no fim das contas, a sua ânsia. ““Estou perdido!', disse a mim mesmo. Ou: 'Estou louco.' E decidi que não podia mais ficar na biblioteca" (ECO, 2017, p. 273), pensa ao escapar do labirinto. Mas acaba na cozinha, onde encontra uma moça, que fica diante dele "como Eva devia ter aparecido a Adão no jardim do Éden" (ECO, 2017, p. 277). Todo o encontro sexual é narrado pelo velho Adso de Melk com a exuberância da nostalgia e a culpa que passou a carregar. "Então, jovem, não pensei na morte, mas, vivaz e sinceramente, chorei pelo meu pecado" (ECO, 2017, p. 281).

A mulher como tentação é outro tema comum em $O$ nome da rosa, cujas dezenas de personagens são, exceto uma, masculinas. A única mulher que participa da ação, ainda que brevemente, é a moça com quem Adso pratica a "conjunção carnal” (ECO, 2017, p. 280), que depois é condenada à fogueira, acusada de bruxaria pelo inquisidor Bernardo Gui. Adso sente por ela um “mal de amor" (ECO, 2017, p. 341), apesar de não entender as suas palavras de camponesa pobre e apesar, como mais tarde ele reflete, de nunca ter sabido o seu nome: "Do único amor terreno de minha vida não sabia, e nunca soube, o nome" (ECO, 2017, p. 433).

Guilherme, estudioso sensato - e propositadamente anacrônico, pois traz consigo ideias modernas - que é, consola Adso por seu pecado indulgentemente, dizendo-lhe sobre a mulher: “Todavia, Adso, eu não consigo convencer-me de que Deus tenha querido introduzir na criação um ser tão imundo sem dotá-lo de alguma virtude” (ECO, 2017, p. 283). Adso, por sua vez bastante medieval, carrega consigo a culpa do "encontro pecaminoso" (ECO, 2017, p. 309).

Com o tempo, aliás, Adso parece se aproximar mais da filosofia de Ubertino do que da de Guilherme. Em sua idade avançada, o narrador, já bem distante do noviço que fora, declara: "Mais velho me torno e mais me abandono à vontade de Deus, e aprecio sempre menos a inteligência que quer saber e a vontade que quer fazer: e reconheço a fé como único elemento de salvação, que sabe esperar paciente sem questionar demasiado" (ECO, 2017, p. 420). A maturidade teria apaziguado a curiosidade que experimentara na juventude, afastando-o, portanto, da busca obsessiva pelo conhecimento que tornava tão vaidoso - tão humano? - o seu antigo mestre. 


\section{Considerações finais}

O nome da rosa termina com um tom agridoce no que diz respeito ao conhecimento e a quem o controla. Adso de Melk, um dia discípulo de Guilherme de Baskerville, um homem apaixonado pelo saber, distancia-se dessa "ânsia da mente" ao aceitar a fé como o único elemento da salvação. A própria investigação protagonizada por Guilherme mostra que o intelecto nem sempre conduz à verdade; toda a sua capacidade de relacionar signos não o poupou de se fiar em meras coincidências. Ao se dar conta disso, sente-se tolo, ainda que Adso, seu fiel companheiro na jornada pelo labirinto, o console.

Em seu espelhamento do mito fundador do Gênesis, $O$ nome da rosa retrata o desejo por conhecimento do homem como algo que o aproxima de Deus e, ao mesmo tempo, pode levá-lo à queda e à ruína. Jorge de Burgos tenta controlar o acesso ao conhecimento, o que, por fim, o conduz à medida extrema de engoli-lo (literalmente, pois devora as páginas envenenadas do livro) e, assim, acaba também engolido pelo inferno, quando o incêndio toma conta da torre da biblioteca. Guilherme e Adso parecem se salvar porque não chegam a devorar o livro - ou fruto - proibido.

Com base nas explicações a respeito da biblioteca labiríntica encontradas no "Pósescrito a $O$ nome da rosa", depreende-se que Eco construiu o labirinto de seu livro cuidadosamente, consciente da multiplicidade de interpretações que se desdobraria a partir dele - e de outros elementos concebidos com igual minúcia, como a arquitetura da abadia como um todo e as misteriosas mortes dos monges que norteiam a trama detetivesca. Assim, como uma última observação, é relevante salientar mais uma vez que o cruzamento entre o "livro proibido" de $O$ nome da rosa e o fruto proibido do Gênesis bíblico constitui uma possível leitura interpretativa da interdição de acesso ao conhecimento que perpassa toda a temática do romance de Eco. Outras leituras têm sido propostas ao longo das décadas e ainda serão propostas no futuro. $\mathrm{O}$ aprofundamento na relação entre a figura do labirinto e a conexão de cadeias semióticas tal qual proposta por Deleuze e Guattari pode ser um dos caminhos de interesse para futuras investigações, entre tantos outros que certamente continuarão se multiplicando a partir de $O$ nome da rosa. 


\section{Referências}

BACON, Francis. Bacon's Novum Organum - Fowler. Londres/Oxford: Claredon Press, 1878. Ebook. Disponível em: https://archive.org/details/baconsnovumorga01fowlgoog/page/n7. Acesso em: 15 out. 2019. BAXTER, David G. "Murder and Mayhem in a Medieval Abbey: The Philosophy of The Name of the Rose". The Journal of Speculative Philosophy 3, n. 3, 1989, p. 170-89.

BIEDERMAN, Hans. Dictionary of symbolism: cultural icons and the meanings behind them. Tradução para o inglês de James Hulbert. Nova York / Oxford: Facts on File, 1992.

CIRLOT, J. E. A dictionary of symbols - second edition. Traduzido do espanhol por Jack Sage. Londres: Routledge, 2001.

COTTER, David W. Genesis (Berit Olam: Studies in Hebrew Narrative \& Poetry). Collegeville (Minnesota): The Liturgical Press, 2003.

DELEUZE, Gilles; GUATTARI, Félix. Mil platôs: capitalismo e esquizofrenia. Vol. 1. Tradução de Aurélio Guerra Neto e Celia Pinto Costa. São Paulo: Editora 34, 2000.

ECO, Umberto. De bibliotheca (I Quaderni de Palazzo Sormani, 6 - Comune di Milano, 1981). Tradução de Ana Lúcia S. Labigalini, Cesar Casella, Flora Mariottini e outros. Campinas: Unicamp, $2004 . \quad$ Disponível em: https://www4.iel.unicamp.br/biblioteca/arquivos/Eco_Umberto_De_Bibliotheca.pdf. Acesso em 15 out. 2019.

ECO, Umberto. Obra aberta. Tradução de Giovanni Cutolo. São Paulo: Perspectiva, 1991. ECO, Umberto. O nome da rosa. Tradução de Aurora Fornoni Bernardini e Homero Freitas de Andrade. Rio de Janeiro: Record: 2017.

ECO, Umberto. Reflections on The Name of the Rose. Londres: Secker \& Warburg, 1985. FERBER, Michael. A dictionary of literary symbols - second edition. Nova York: Cambridge University Press, 2007.

GARRETT, Jeffrey. "Missing Eco: On Reading 'The Name of the Rose' as Library Criticism”. The Library Quarterly: Information, Community, 4, 1991, p. 373-388.

GÊNESIS. Tradução de Alexandro Zir. Porto Alegre: L\&PM, 2001.

GUIMARÃES, Denise Azevedo Duarte. “A Idade Média revisitada por Umberto Eco”. Letras, Curitiba, n. 37, p. 208-223 
HAFT, Adele J.; WHITE, Jane G.; WHITE, Robert J. The Key to 'The Name of the Rose': including translations of all non-English passages. Ann Arbor (MI): University of Michigan Press, 1999.

HARTOG, François. O espelho de Heródoto - ensaio sobre a representação do outro. Tradução de Jacyntho Lins Brandão. Belo Horizonte: UFMG, 1999.

KURY, Mário da Gama. Introdução. In: SÓFOCLES. A trilogia tebana: Édipo Rei, Édipo em Colono, Antígona. Rio de Janeiro: Zahar, 2011.

SWAIM, Kathleen M. “The Art of the Maze in Book IX of Paradise Lost”. Studies in English Literature, 1500-1900 12, n. 1, 1972, p. 129-40.

TERZIEVA-ARTEMIS, Rossitsa. "The Name of the Rose and the Labyrinths of Reading". In: BLOOM, Harold; HOBBY, Blake (Ed.) Blooms's Literary Themes: The Labyrinth. Nova York: Bloom's Literary Criticism (Infobase Publishing), 2009). p. 173-184.

TOWNER, W. Sibley. Genesis. Louisville: Westminster John Knox Press, 2001.

TRESSIDER, Jack. The Watkins dictionary of symbols. Londres: Watkins Publishing, 2012. VOGL, Joseph. Ein Labyrinth ohne Anfang und Ende. Was ist ein RHIZOM? Disponível em: https://www.dctp.tv/filme/prime-time-30-09-2007. Acesso em 15 out. 2019.

Artigo recebido em: 29.10.2019

Artigo aceito para publicar em: 04.12.2019 